REPORTS FROM MEETINGS

\title{
Second Seminar on Diabetes and First Yugoslav Symposium on Diabetes Zagreb, October 21-28, 1967
}

\section{ZDENKO SKKRABALO}

Received: August 6, 1968

Towards the end of October 1967 two meetings of diabetologists from all parts of Yugoslavia took place in Zagreb: the Second Seminar on Diabetes (October 21-25) and the First Yugoslav Symposium on Diabetes (October 25-28). Their importance was enhanced by the active participation of the representatives of the Yugoslav social organizations of diabetics: the Federation of the Associations of Diabetics of Yugoslavia and the Association of Diabetics of Croatia on the one hand, and the eminent diabetologists from various European countries, the Soviet Union, the United States, on the other.

On the first day of the Seminar all the heads of the Centres and Dispensaries for Diabetes present at the Seminar gave brief reports on the organization and methods of work as applied in their institutions. During the following days the participants of the Seminar attended lectures on various problems of diabetes.

The opening of the First Yugoslav Symposium on Diabetes took place on October 25th, 1967. The Working programme lasted until October 27th and was attended by 120 participants from Yugoslavia, as well as foreign guests from Austria, Holland, USA, USSR, Chile, Czechoslovakia, Democratic Republic of Germany, Bulgaria, Great Britain, and Federal Republic of Germany. Among them there was also Dr. J.J. WITTE, Secretary-General of the International Diabetes Federation.

The First day of the Symposium was devoted to the problems of the health protection of diabetics and the current state of his protection in the individual parts of Yugoslavia, the organization of the service in some other countries, and a number of socio-medical problems the Yugoslav health workers are faced with in the health protection of diabetics in Yugoslavia. The second and third days of the Symposium were devoted to various problems of the pathophysiology, diagnosis and therapy of diabetes.

The Second Seminar on Diabetes and the First Yugoslav Symposium on Diabetes held in Zagreb in the autumn of 1967 have attained their goal. Health workers from all over Yugoslavia concerned with the problems of diabetes were given the opportunity to meet and get nearer to each other. They also had the chance of meeting foreign diabetologists from Eastern and Western Europe, the USSR, and the USA. It is to be hoped that this encounter will be a stimulus for further collaboration between the Yugoslav health workers themselves and a collaboration in this field on a much wider, international scale.

Zdenko Šrrabato, M.D., D.Sc. Centre for Diabetes "Vuk Vrhovack Department of Medicine General Hospital "Ozren Novosel" Medical school, University of Zagreb Zagreb, Yugoslavia 